\title{
Judaism and Jewish Business Practices
}

\author{
Samuel L. Dunn ${ }^{1} \&$ Joshua D. Jensen ${ }^{1}$ \\ ${ }^{1}$ School of Business, Northwest Nazarene University, Nampa, Idaho, USA \\ Correspondence: Samuel L. Dunn, School of Business, Northwest Nazarene University, 623 S. University Boulevard, \\ Nampa, Idaho 83686, USA.
}

Received: June 13, 2018

Accepted: June 27, 2018

Online Published: July 3, 2018

doi:10.5430/ijba.v9n4p73

URL: https://doi.org/10.5430/ijba.v9n4p73

\begin{abstract}
Today's global business environment is extremely diverse. With the business tools and resources that are available today, organizations of any size can create a global footprint easier than ever before. Today's business professionals must be educated and trained in how to effectively interact with multiple cultures in order to successfully navigate the global business environment. Knowledge, acceptance, and appreciation of various cultures along with a fervent understanding of business practices in various cultures is required of the $21^{\text {st }}$ century global business professional. This paper focuses on Jewish culture and how it manifests itself through Jewish business practices. The purpose of this paper is to give the reader a basic understanding of the principal branches of Judaism, a history of Judaism, an explanation of Jewish beliefs, and an introduction to Jewish business practices in hopes that further study will be elicited.
\end{abstract}

Keywords: global business, cross-cultural business, Judaism, Jewish business practices

\section{Introduction}

The purpose of this paper is to provide to the reader information concerning the Jewish religion and Jewish business practices. This paper is the second of four papers about religious influence on business practices. The first was a paper about Islamic finance, which examined Islam and Islamic business practices (Dunn \& Galloway, 2011). There is to follow papers on Hindu and Buddhist Business Practices.

Emerging markets increasingly drive change in the business world today. "By 2025, almost half of the world's biggest companies will probably be based in emerging markets, profoundly altering global competitive dynamics" (Dobbs, Remes, Smit, Manyika, Woetzel, \& Agyenim-Boateng, 2013, para. 1). Emerging markets will continue to change and shape the landscape of the $21^{\text {st }}$ century global business environment going forward. This will require business professionals to acquire new knowledge and skills, most importantly related to cross-cultural behavior and communication.

Business professionals working in today's global business environment will likely be interacting at some point with Jewish business professionals in many countries of the world. The economy of Israel is robust and dynamic, with extensions in many Western countries. It behooves the typical global businessperson to know what Jews believe and how they conduct business. This will greatly increase the likelihood that a successful business interaction will occur.

Throughout the paper the first usage of terms coming from Hebrew or other foreign languages will be italicized. The names of books sacred to Judaism will also be italicized. We begin with a description of Judaism.

\section{Judaism}

Judaism is simultaneously a culture and a religion. Jews who are religious accept belief in a God and observe Jewish law (halakha). However, many individuals who identify as Jews do not believe in the religion. Over half the Jews in Israel view themselves as secular Jews and do not follow Jewish religious beliefs or practices.

The United States Supreme Court ruled in the 1980s that the Jews constitute a race so far as some aspects of U.S. law is concerned. However, Jews come from all races, colors and ethnicities, and should not be considered as a cohesive ethnicity.

The world population of Jews is around 14 million. Countries with the most Jewish population are ("Vital Statistics," 2016): Israel with 6.3 million; United States with 5.7 million, Canada with 388,000, United Kingdom with 290,000, Argentina with 181,000, Russia with 180,000, Germany with 117,000, and Australia with 113,000. 


\subsection{Observant Jews}

An Observant Jew is one who follows and complies with Jewish law, halakha, as contrasted with one who is a Jew by birth or by culture. Exactly what laws are to be followed to be considered observant is ambiguous, but most would agree that following the Sabbath laws and kosher eating laws would be required.

The laws, rules, and business expectations described in this paper are those that apply to observant Jews.

\subsection{Branches of Judaism}

There are three main branches of Judaism as a religion: Orthodox, Conservative, and Reform. In the United States " $10 \%$ consider themselves Orthodox, $18 \%$ consider themselves Conservative, 35\% Reform and 30\% no denomination" ("Orthodox," 2016).

\subsubsection{Orthodox Judaism}

The most conservative of the three main groups is the Orthodox Judaism branch. Orthodox Jews believe that both the Torah and the Oral Torah come directly from God (see descriptions of these below). The laws contained in the Torahs are to be followed strictly. The law dictates all matters of life, such as family relations, food, sex, and observance of the Sabbath day.

There is not just one Orthodox Jewish group, but many groups that emphasize different aspects of the law and its relationship to culture. Principal subgroups include the Chasid and the Yeshiva groups, which are among the strictest observers. Both of these groups emphasize study and learning of the Jewish Scriptures. Some groups, known as the Kabbalah, emphasize the mysteries of Jewish beliefs. Orthodox Jews accept the 13 Principles outlined by Maimonides (see below).

Orthodox Judaism is very conservative in accepting converts. Male converts must be circumcised and both men and women must be baptized. The baptismal ceremony may be done by total immersion; in another method the officiant pours water over the baptismal candidate who is standing in the water.

\subsubsection{Conservative Judaism}

Conservative Judaism is the middle of the road group among observant Jews. Conservative Jews accept that some elements of Judaism must be modernized under the guidance of current rabbis.

Conservative Judaism arose in the early 1800s in response to Reform Judaism. Conservative Jews accept the Torah and Talmud and believe that the halakha sets the standards, but believe they should be adapted to modern usages. Not many Conservative Jews follow all the laws all the time, but they still observe most of the kosher and Sabbath laws. Women may become rabbis. Just as among the Orthodox Jews, there are many branches of Conservative Judaism. Conservative Judaism has its greatest followings in the United States.

Conservative Judaism welcomes converts. Male converts must be circumcised and both men and women must be baptized.

\subsubsection{Reform Judaism}

The most liberal of the three principal Jewish groups is Reform Judaism. It also began in the early 1800s and focused on relief from the strict observance of halakha.

While Reform Jews believe in a monotheistic God, they believe the Torah and Talmud are human products, books written by people who reflected the science and cultural understandings of their times. However, there are principles in the halakha that apply to our times. Revelation of truth occurs continuously.

Reform Judaism emphasizes study of the Scriptures, living an ethical life, celebrating the principal life events, survival of Judaism, and living a life of holiness. There is no religious hierarchy in Reform Judaism. Equality of genders is emphasized. Converts are welcome; male converts do not have to undergo circumcision ("Circumcision," n.d.). A Messianic Age to come is believed, but not a personal Messiah.

Children born of Jewish parents are considered to be Jews. Children born in interfaith marriages are considered Jewish if the parents identify the child as Jewish and raise the child with appropriate public acts that are Jewish in nature.

The World Union for Progressive Judaism, headquartered in Jerusalem, is the umbrella world organization for Reform Judaism. 


\subsubsection{Messianic Judaism}

Messianic Jews are Jews who have accepted Jesus as their personal Messiah. There are an estimated 350,000 Messianic Jews in the world. Many Jews do not accept Messianic Jews as being true Jews ("Messianic," n.d.).

\section{Jewish History}

\subsection{Pre-Abraham}

God created the heavens and the earth. God brought order out of chaos and created the animals, fish, birds and plants of the earth. God created humankind in his own image; Adam and Eve, the first humans, were created. God rested on the seventh day.

Adam and Eve lived in a Garden of Eden, but did not follow God's commandments and were expelled from the Garden. From that time on humans had to work for their living. Adam and Eve bore children who married and had children, thereby populating the earth with humans. Humans lived in gross sin, so much so that God regretted that He had created humans, and vowed to destroy all human life.

Before destroying humanity God saw there was one person, Noah, who was living a righteous life. At God's direction Noah built an ark for himself, his family and representatives of the animals of the earth. The ark protected these people and animals in a great flood that filled the earth. Eventually the waters of the flood receded and Noah and family started human life and civilization again.

One of the descendants of Noah, several generations removed, was a man named Abraham.

\subsection{Abraham}

Jewish history is normally assumed to have begun with this man named Abraham. Abraham lived in Ur of the Chaldeans, a city east of the modern state of Israel. Ur has not been positively identified; some scholars believe it was a town in southern Turkey, while others believe it was a town in what is now Iraq.

Abraham was called by God to move with his family to the land of Canaan on the western side of the Fertile Crescent. The year was approximately $1800 \mathrm{BC}$. Abraham moved to an area near to what is now the modern city of Hebron, Israel. In Canaan God made a special covenant with Abraham, telling Abraham that he would be the father of many nations and that he and his descendants would possess the surrounding nearby land.

Abraham and his maidservant bore a son named Ishmael. Ishmael became the father of many peoples, many descendants of which in later centuries embraced Islam. Abraham's wife Sarah bore a son, Isaac, who in turn bore a son Jacob, (later named Israel), who in turn bore 12 sons. The descendants of Israel were divided into 12 divisions, most of which were named after the sons of Israel. The divisions were called tribes and the people became known as the Israelites. [A later descendant of Abraham was Jesus of Nazareth, whom Christians regard as the Messiah. None of the three main branches of Judaism regard Jesus as the Messiah. The three religions: Judaism, Islam, and Christianity are known as the Abrahamic religions].

\subsection{Joseph, Egypt and the Exodus}

One of the sons of Jacob was a man named Joseph, who through a series of miraculous occurrences was transported to Egypt where he became vizier to the Egyptian Pharaoh. Joseph saved his family's lives when they moved to northern Egypt as a result of a famine in Canaan. After 400 years the descendants of Joseph grew so numerous that they posed a threat to Pharaoh, who mistreated these people, so God chose Moses to lead the people back to Canaan.

Through a series of miracles the people were able to escape from Egypt and head back home to Canaan. They wandered for 40 years in the wilderness east of Egypt until eventually they got back to Canaan in approximately the year $1400 \mathrm{BC}$.

During that period of wandering God gave Moses the Torah and the Ten Commandments, which became the foundation for life and law among the Israelites.

\subsection{The Period of Judges}

When the Israelites came to Canaan they found the land occupied by other groups. By God's order the Israelites occupied the land by force. The land was divided into 11 regions for 11 of the 12 tribes; one of the tribes was selected to be the priestly tribe and did not have assigned land.

For a period of 400 years the people were ruled by righteous people raised up by God to deliver the people from surrounding oppressors and to judge the people. Often these leaders were tribal judges or clan leaders who used the 
laws and commandments given to Moses as the legal foundation for life and living. The legal system was highly decentralized.

\subsection{The Kingdom}

After the lengthy experiment with decentralization, the people felt the need to establish a Kingdom. In approximately 915 BC Saul was picked as the first king, who was succeeded by David, who made Jerusalem his capital. David was followed by his son, Solomon. These three kings marked the high period of the Kingdom of Israel. During Solomon's reign the Kingdom grew in size to include land ranging from what is now part of lower Syria down to the Sinai Peninsula, and from the Mediterranean over into what is now the country of Jordan. Solomon also built a major temple in Jerusalem in approximately $830 \mathrm{BC}$.

After Solomon's death a civil war broke out between the 10 tribes to the north and the two tribes in the south. The war led to a division of the country into two smaller countries. The northern 10 tribes became the Kingdom of Israel and the two southern tribes became the Kingdom of Judah. The dominant tribe in the south was the tribe of Judah, so the southern kingdom was known as the Kingdom of Judah and its people were known as the Jews.

\subsection{The Exile}

The northern kingdom, Israel, was conquered by Tiglath-Pileser III, King of Assyria, in the $8^{\text {th }}$ century BC; Tiglath-Pileser sent many of the people into exile in the surrounding countries. These people, according to the historical narrative, never came back to their homeland; these 10 tribes are today known as the Lost Tribes of Israel.

In $587 \mathrm{BC}$ the southern Kingdom of Judah was conquered by the Babylonians, whose capital was Babylon in what is now Iraq. Solomon's temple was destroyed. Key leaders were taken to Babylon and held in exile and then were allowed to return to their homeland after the Persians conquered Babylon in 540 BC. Many Jews stayed in Babylon which became the center of Jewish culture practice for over a thousand years. It is estimated that there were 2 million Jews in Babylonia in the year $500 \mathrm{AD}$.

It was during the time of the Exile in Babylon that the synagogue system was developed. This system is still used to this day in all three branches of Judaism and is considered to be the precursor of the Christian church system as well.

\subsection{Domination by Foreign Powers}

After the return from Exile to Judah the people rebuilt the Temple in $516 \mathrm{BC}$ and enjoyed peace under the Persians for approximately 200 years. In $332 \mathrm{BC}$ the Persians were conquered by Alexander the Great and the Greek language and culture were introduced to the Jewish people. After Alexander's death the empire was divided among Alexander's generals, and the Jewish state came under the Seleucid Greek Kingdom.

The Jews revolted in 167-160 BC against the Seleucid Greeks and created the Hasmonean Kingdom, which existed until 63 BC when the land was conquered by the Romans under General Pompey. The Romans allowed the people of Judah to keep their religion and have a puppet king who ruled under the direction of Roman viceroys (Whitmarsh, 1981). During this period Jewish merchants brought their businesses to the cities of the Roman world. Jewish enclaves could be found in most principal cities of the Roman world and beyond.

\subsection{Rabbinic Judaism}

The people of Judah chafed under Roman rule and periodically revolted against the rulers. After a particularly lengthy revolt which began in $66 \mathrm{AD}$, the Romans in $70 \mathrm{AD}$ under the direction of the Emperor Vespasian and the military leadership of Titus, attacked the country, sacked Jerusalem, and tore down the Temple.

Without the Temple the Jewish sacrificial system was destroyed, so the centralized system of worship of the Jews was eliminated. From the party known as Pharisees, a group of leaders convened who developed laws and rules that would be used to govern worship, law, and life without the temple and the centralized worship of God. These leaders and others contributed important writings to give guidance to the Jewish people, wherever they lived in the world.

The Jews spread around the known world after the Exile, and especially after the fall of Jerusalem in 70 AD. This significant movement of people is known as the Jewish diaspora. While most Jews moved out of Israel, a small minority stayed in the country over the centuries.

\subsection{Middle Ages to 1500}

By the time of the Middle Ages Jews lived in all parts of Europe, western Asia, and northern Africa. Their treatment by the majority societies varied from jurisdiction to jurisdiction. In general, Jews were treated as second-class citizens, but were protected citizens in Muslim countries. At times there were pogroms against the Jews, with forced 
conversions to the dominant religion. In the West in the year 1215 the Fourth Lateran Council decreed that Jews had to wear distinctive clothing.

Throughout the Middle Ages the official stance of the Christian churches was to bring the Jewish people into conversion to Christianity. During those years the conversions were often forced. In Spain forced conversions officially began in 1391 (Jackson, 1972). Jews were subject to derision and hatred in many parts of Europe. They were labeled as Christ-killers and accused of sacrificing babies. They were often portrayed as low-life criminals in the dramas of the day.

During the late Middle Ages there was a significant growth of cities in Europe. Businesses, cathedrals, and universities drew populations to those city centers. Funding of city services came from land, tuition from students, business levies, and special taxes on minority groups such as Jews and Muslims.

[Cities also] drew income from banking and mortgaging land, which could raise considerable sums when nobles were running into financial difficulties, or churches were caught midway in expensive building programs. Jews, unencumbered by the Christian prohibition of usury, played a prominent part in these activities, and paid a heavy cost for it. They were liable to pogroms, such as those which swept the Rhineland cities in 1096, and to arbitrary levies by their lords; when the king of France arrested the Jews in the crown lands in 1180, he was able to ransom them for the considerable sum of 15,000 marks. (Holmes, 1988, p. 129)

Especially hateful to many Christians was the ability of the Jews to be bankers and to lend money with usurious interest. Traditionally, Christians were not allowed to charge interest and even as late as 1750 Pope Benedict XIV issued the Bull Vix Pervenit which prohibited all interest, not just usurious levels of interest.

Jews in Spain played an important role in bringing ancient textual material into Europe. "Jewish scholars ... made a major contribution. They could move with ease between Latin, Hebrew, and Arabic and often provided a vital link in the chain of translation" (Holmes, 1988, p. 208). Much of the known philosophical material from ancient Greece and Israel came from the translations from Greek and Hebrew into Arabic and then into Latin, and thus became available to Europeans (Southern, 1953).

On the Iberian Peninsula conditions for the Jews worsened and the Inquisition, which officially began in 1478 , enforced conversion laws, leading up to 1492. In 1492 Spain expelled Jews and Muslims from the country, unless they converted to Christianity. Many of the Jews migrated to North Africa where they lived under Muslim rule. Some stayed in Spain or Portugal while pretending to convert.

\section{$3.101500-1945$}

Conditions for Jews gradually worsened over the 400 year period leading up to World War II, while at the same time Jews began to call for a return to their traditional homeland, Canaan, known as the Holy Land. In many cities the Jews were forced to live in Jewish enclaves. World War I saw a particularly brutal persecution of Jews by Russia, forcing many to the West. It also saw a resurgence of the idea of creating a Jewish homeland. World War I also created the economic conditions leading to scapegoating of the Jews in Europe. In the late 1930s serious persecution of Jews began to take place in areas controlled by Hitler's Nazi party. In the early 1940s the Nazi's Third Reich began to exercise the "Final Solution," the goal of which was to exterminate the Jews. Approximately six million Jews were killed in the resulting Holocaust.

\subsection{The State of Israel}

Over the centuries, Jews began to migrate back to the Holy Land and began to agitate for a Jewish state to be formed. Immediately after World War II the Holy Land, which comprised the moderns states of Israel, Jordan, Lebanon and Syria, was still under British control. Control had been given to Great Britain after World War I. Jewish commandos began a guerilla war against the British because of Great Britain's policy limiting immigration to the Holy Land, even immigration by European Jews being persecuted by the Third Reich. Their resistance eventually forced the British out. The Jewish state of Israel was formed in 1948 and recognized by major world powers. There was a war at that time between Israel and surrounding Arab countries over the lack of provision for Arabs living in Palestine; the war concluded in 1949. Israel won the war and established itself as a viable country and government.

The current state of Israel has approximately eight million inhabitants, of which six million are Jews. The remainder are mainly Arabs, mostly Muslim and some Christian. Non-Jewish citizens of Israel have limited rights in the country. 
In Israel the Orthodox Jews have much power in governance, more power than their numbers would normally support in a democracy. Most of the citizens, however, are secular Jews and do not practice the Jewish religion.

There are also cultural divisions in Israel based on the region from which the citizens migrated to come to Israel. Sephardic Jews are those that are descendants of Jews from the Iberian Peninsula and the Spanish diaspora. Ashkenazic Jews are those that came from Central and Eastern Europe, although now it typically refers to any Jews from Europe. Mizahi Jews are Asiatic Jews, typically from Iraq, Iran and Yemen. Jews born in Israel are often referred to as Sabras.

Given Israel's geographic location, its culture is difficult to understand in terms of Hofstede's (n.d.) categorization. It does not share many cultural elements with its Middle Eastern neighbors. The principal reason it is different is that its culture is shaped by first- and second-generation immigrants who have come from all parts of the world, people who generally favor democratic government and lean toward religious Judaism rather than the predominant Arab Islamist tendencies of Israel's neighbors (Tole, 2012).

The six Hofstede indices (Hofstede, Hofstede, \& Minkov, 2010; Hofstede, n.d.) are:

\begin{tabular}{lllll}
\hline & Israel & Arab Countries & United States & Great Britain \\
\hline Power Distance & 13 & 80 & 40 & 35 \\
Individualism & 54 & 38 & 91 & 89 \\
Masculinity & 47 & 53 & 62 & 66 \\
Uncertainty Avoidance & 81 & 68 & 46 & 35 \\
Long Term Orientation & 38 & 7 (Egypt) & 26 & 51 \\
Indulgence & N/A & 4 (Egypt) & 68 & 69 \\
\hline
\end{tabular}

Several countries in Israel's region want Israel to be eliminated as a country and the region returned to Muslim control. However, Israel does have a peace treaty with the countries of Jordan and Egypt.

At the time of this writing the economy of Israel is quite strong. Israel is a hub for high tech development. The standard of living is similar to that in western European countries.

\subsection{Judaism in the United States}

There are approximately six million Jews in the United States. About $10 \%$ of them are orthodox Jews. Jews in the United States are full citizens and enjoy all privileges granted to U.S. citizens. Jews hold many leadership positions in government, science, the universities, medicine, and business.

Relationships between Jews and Christians are generally positive in the United States. Notable improvements came after the Catholic Ecumenical Council Vatican II when it became the official position of the Roman Catholic Church that the Jews were not culpable in the death of Jesus. While conditions are generally positive, there are still occasional acts of violence against Jewish synagogues.

\subsection{Synagogue Worship}

The Sabbath day is a 25-hour period that begins at sundown on Friday. All three major branches of Judaism respect Sabbath day worship in the synagogue.

Sabbath services normally take place on Friday evening; there may also be a Saturday morning and Saturday afternoon service. The place of worship, the synagogue, is traditionally built facing Jerusalem. At the end of the synagogue facing Jerusalem there is a raised area on which stands the Ark, a cabinet construct which holds the Torah. The Torah is typically contained on scrolls. There will normally be a menorah on the raised platform.

Seating will be similar to that of a Christian church. In orthodox synagogues the men and women sit in separate sections; women sometimes sit in a balcony. In Conservative and Reform synagogues the men and women sit together. Generally the more conservative the congregation, the more formal is the attire. Men may wear a yarmulke and a prayer shawl.

During the service each person will typically have a prayer book which contains readings and prayers in Hebrew and the common language. There will be readings from the Psalms, a recitation of the attributes of God, a recitation of the Shema (Hear O Israel, the Lord our God, the Lord is One), a time for silent prayers, a reading from the Torah and other Scriptures, and a chanting of blessings. There may be hymns sung by the congregation, and there may be a sermon which will typically be based on the Torah reading of the day (Geffen, n.d.; "Synagogue," n.d.). 


\section{Jewish Beliefs}

\subsection{Sacred Writings}

Judaism is known for its scholars, teachers, writers and prophets. A plethora of materials written over three thousand years is available that discuss the faith. The principal writings and collections are discussed below.

\subsubsection{The Torah}

The primary sacred book in Judaism is the Written Torah. This is the first five books of Moses, sometimes referred to as the Pentateuch; these are the same as the first five books of the Christian Bible. The Written Torah contains 613 commandments which provide the basic guidance for life's activities ("Torah," n.d.).

There is also the Oral Torah which is a collection of writings believed to have been taught to Moses by God. The Oral Torah gives explanations of the written Torah and states how to interpret the written Torah for everyday life. The Oral Torah was maintained in oral form until the $2^{\text {nd }}$ century AD when it was written down in a document named the Mishnah. Over time more writings were added in both Jerusalem and Babylon. These additions are called the Gemara. In the remainder of this paper the word Torah will refer to the Written Torah.

\subsubsection{The Talmud}

The Mishnah and the Gemara together are known as the Talmud. The word "Talmud" means "learning" or "instruction" in Hebrew. Two versions of the Talmud are now recognized: the Babylonian Talmud and the Jerusalem Talmud. The Babylonian Talmud is the one now most used and read. The Talmud is divided into 54 sections; each Sabbath day one of the sections is read in the morning service.

\subsubsection{The Hebrew Bible}

The Torah, the writings of the prophets, and various other writings make up the Hebrew Bible (known to Christians as the Old Testament). Sometimes the Hebrew Bible is referred to as the Tanach.

The Tanach is divided into three main sections: the Torah, the Prophets, and the Writings. The Prophets is again divided into two groups: the Earlier Prophets and the Later Prophets. The Writings are divided into three groups: The Poetic Books, the Five Scrolls, and the Other Historical Books.

\subsubsection{The Midrash}

The Midrash is a set of writings that contain the commentaries of Talmudic scholars over the centuries.

\subsubsection{The Responsa}

The Responsa are legal decisions, handed down by Jewish scholars and leaders, which provide significant guidance for today's Jewish law. These are not found in one book, but are in scattered sources.

\subsection{Concept of God}

It is believed by some scholars that the concept of God evolved over the centuries of pre-Jewish and Jewish history. In earliest times the predecessors of the Jews believed that every nation had a god. As time passed the Jews came to believe that every nation had its god, but the God of the Jews, Yahweh, was the most powerful God. The third concept in this development was the belief by the Jews that there was only one God, their God, Yahweh, and all other gods were false gods (Kohler, 2015). Since most of the Old Testament was put in written form after the Exile, this third concept of God dominates the Old Testament.

Yahweh is One, a unitary being. He is incorporeal, and thus is neither male or female. He is omnipresent and omnipotent. He created the heavens and the earth and all human, animal and plant life. Yahweh, God, remains in contact and communication with his human creation.

It is fundamental that God is distinct from creation. "God is not to be identified with anything on earth. This ontological divide is fundamental. God is God; humanity is humanity. There can be no blurring of the boundaries" (Sacks, 2010, loc 953). Every Jew is to love God, and all of life is to be a reflection of that love. Each Jew is required to recite the Shema two times each day. The Shema is found in the book of Deuteronomy 6:4: "Hear, Israel: The Lord is our God, The Lord is one."

\subsection{The Ten Commandments}

Contained in the Torah are ten particular commands that were given to Moses by God. These ten commandments form the bedrock rules of life and law for the Jewish people. They are found in the books of Exodus and Leviticus. A short version of the Ten Commandments follows: 
1. You shall have no other gods before Me.

2. You shall not make idols.

3. You shall not take the name of the LORD your God in vain.

4. Remember the Sabbath day, to keep it holy.

5. Honor your father and your mother.

6. You shall not murder.

7. You shall not commit adultery.

8. You shall not steal.

9. You shall not bear false witness against your neighbor.

10. You shall not covet.

\subsection{The 613 Rules}

Contained in the Torah are various affirmative and negative rules that every righteous Jew is supposed to follow. These are rules that must be followed at all times. They cover most aspects of daily life (Mitzvot, 2011).

Many of these 613 rules applied to Temple worship and the sacrificial system. Since the Temple no longer exists and the sacrificial system is no longer in place, many of the rules have no application today.

In the authors' analysis, 116 of the 613 laws apply to the practice of business (Mitzvot, 2011).

\subsection{The Thirteen Principles}

These principles were proposed by Moses Maimonides (1135-1204 AD), a Jewish philosopher, astronomer and physician. Many Jewish works refer to him by the acronym of his title and name: Rambam. Maimonides took the 613 rules and condensed them to 13 basic beliefs of Judaism, as follows:

1. God exists.

2. God is one.

3. God is a spirit and incorporeal.

4. God is eternal.

5. God alone is to be the object of worship.

6. Revelation comes through God's prophets.

7. Moses is preeminent among the prophets.

8. God's law was given on Mount Sinai.

9. The Torah as God's law is immutable.

10. God has foreknowledge of human action.

11. There will be reward for good and retribution for evil.

12. The Jewish Messiah will come.

13. There will be a resurrection of the dead.

\subsection{The Messiah}

Jews do not believe in a personal Messiah who is divine or semi-divine as do Christians. In order to distinguish Jewish beliefs in a Messiah from Christian beliefs, some Jews refer to the Messiah by the name Mashiach.

The mashiach will be a great political leader descended from King David (Jeremiah 23:5). The mashiach is often referred to as "mashiach ben David" (mashiach, son of David). He will be well-versed in Jewish law, and observant of its commandments (Isaiah 11:2-5). He will be a charismatic leader, inspiring others to follow his example. He will be a great military leader, who will win battles for $\underline{I \text { srael. }}$. He will be a great judge, who makes righteous decisions (Jeremiah 33:15). But above all, he will be a human being, not a god, demi-god or other supernatural being. ("Messiah," n.d., para. 7)

Conservative and Reform Jews generally do not believe in a personal messiah, but instead talk about a messianic age, an age of peace. 


\subsection{Creation Care}

The physical universe was created by God. All Jews are to care for and preserve the creation. “...wanton destruction of any kind is a violation of Torah law. This is known as the principle of bal tashchit...a prohibition against unnecessary destruction or waste" (Friedman, 2001, p. 11).

"Wasteful consumption is proscribed by the Torah. Soldiers are not permitted to cut down fruit trees even when besieging an enemy's city (Deuteronomy 20:19)" (Friedman, 2001, p. 11).

The land is to be given a rest every seventh year. This practice keeps the land from being depleted.

Animals are to be treated well. People should not eat until the animals have been fed. Animals are to be rested on the Sabbath, just as people are to be rested. Animals are not to be muzzled when working the fields. Certain animals may be used for food, but they must be slaughtered in a way that does not prolong the suffering of the animal (Genesis 9) ("Ethical Treatment," n.d.).

\subsection{A Chosen Nation}

A core belief in Judaism is that Jews are a chosen people, chosen directly by God. This choice carries with it the responsibility to glorify God and be a light and blessing to the nations of the earth. Any Jew who sins brings shame to God and thwarts the country's witness.

\subsection{Judgement and the After-Life}

After life on earth is finished, a person's soul will be placed in Gehinom (Hell) or Gan Eden (Paradise) according to the person's actions while alive. If the person has done more good deeds than bad deeds, then the soul will go to Gan Eden. If the person has done more bad deeds than good deeds, then the soul will go to Gehinom.

\subsection{Alms}

Persons with means must share with the poor. A traditional goal is to give $10 \%$ of one's income to help persons needing resources. The best giving is to forgive a loan. Best of all is helping a person find a job or resources that take the person out of poverty. On the other hand, persons should not give away their wealth and destitute themselves in the process.

\subsection{Kosher Laws}

Food that is approved to be eaten is said to be kosher. Saying that food is kosher means that it is fit and proper to eat. Eating the meat of some animals, such as swine, is not allowed and hence is not kosher. Only animals that have cloven hooves and chew the cud are allowed to be eaten ("Kosher," n.d.; "Kosher Overview," n.d.). Blood is not allowed to be eaten, and blood must be drained from all meats.

Animals that are allowed for eating must be slaughtered in a particular way for the meat to be considered kosher; the animal must be killed with a single knife stroke. Actions must not lead to the suffering of animals, such as taking eggs from the nest in front of the mother bird. Overfeeding animals to produce exotic foods is not permitted.

Certain birds such as pelicans, eagles, owls, and storks may not be eaten. Geese, ducks, chickens, and turkeys may be eaten. Eggs coming from kosher birds may be eaten. Fish with scales and fins may be eaten, so salmon and tuna are approved. Lobsters, shrimp, and crabs are not allowed.

Dairy products from non-kosher animals may not be eaten or drunk. Milk and meat products may not be eaten or drunk together; they may not be cooked together nor served together at a meal. Drinks coming from grapes may be consumed if prepared by kosher principles.

Insects with many legs, and insects with very short legs are not kosher, but four varieties of locust are kosher. All food products that grow on trees, bushes, or plants or grow in the soil are kosher, but they must be examined to make sure they do not contain forbidden insects. Moreover, fruit coming from trees planted in the last three years is forbidden.

All food utensils must be used only for kosher foods. Any contact with a non-kosher food makes the utensil unclean for use.

\subsection{Jewish Holidays}

Rosh Hasshanah is the start of the Jewish New Year. It represents the anniversary of the creation of Adam and Eve, and is a time of inward reflection and preparation for the year ahead. No work is permitted. Yom Kippur is the Day of Atonement, probably the most important holiday of the year in Judaism. Jewish people traditionally observe this holy day with prayer and fasting, and often spend most of the day in synagogue services. No work is permitted. 
Sukkos is the Feast of Tabernacles, which celebrates the gathering of harvest. During this week-long holiday, work is not permitted in the first couple of days, and limited work with restriction is permitted later in the week. Hannukah is a celebration of the victory of the Maccabees over Syria in 165 BC. During this eight-day celebration, work is permitted. Purim celebrates the victory of the Jews over a wicked enemy, Haman, won by the Jewish Queen of Persia named Esther. Work should be avoided during this holiday. Passover is a week-long celebration of the escape of the Israelites from Egyptian slavery, under the leadership of Moses. It is permissible to work on some days during Passover, and impermissible on others. Shvuoth celebrates the giving of the law to Moses by God on Mt. Sinai. No work is permitted.

\section{Jewish Business Practices}

In this section we describe several aspects of Jewish business practices. We note that there are no one or two unique practices or beliefs that characterize Jewish practices, such as one would find in Islamic business practices with Islam's prohibition against riba (charging interest) and gharar. The reader will note that Jewish business practices are congruent with the best business practices found in conventional Western management.

\subsection{Attitude Toward Wealth and Business}

Judaism has a positive attitude toward wealth and business, provided they are used and practiced according to the Torah and Talmud, which particularly means that wealth must be used to assist the widows, orphans, and the needy in society. High ethical standards must be maintained. Profits in business may be earned provided they do not come to the detriment of other persons.

There are many rules in the Torah and Talmud concerning business conduct. High ethical standards are required of all business professionals. Several of these ethical principles are:

- In selling one must not take advantage of another person's ignorance.

- Fraudulent dealing with any person, whether Jew or Gentile, is prohibited.

- Gains obtained from gambling or betting are prohibited.

- Usurious interest charged for loans or sale of necessities is prohibited.

- Honesty is required in all business dealings.

- No action may expose another to danger.

- Weights and measures must be accurate.

- False and deceptive labeling and packaging is prohibited.

- Laws determined by the city regarding working conditions and compensation are to be followed.

- Taxes are to be paid to the civil authorities, whether they be Jewish or Gentile.

According to one commentator, excessive markups on necessary goods are prohibited. Profits from selling necessities such as wheat, wine, or oil are not to exceed one-sixth (Friedman, 2001, p. 8).

\subsection{Business Ethics}

Ethics in business is not found solely in following the Talmud, but rather it is an approach, an attitude, a desire to be good by doing good.

Friedman ... demonstrates that the Talmudic sages believed that there is an ethics hierarchy and that individuals should strive to reach the summit... Businesspeople leading their lives according to this principle go beyond the letter of the law and are willing to lose money rather than take advantage of another person's misfortune. (Friedman, 2001, p. 4)

Included in the prohibition against stealing is the understanding that deception and dishonesty are forbidden. "Any type of deceptive act or practice, including deceptive advertisements and deceptive packaging, would also be a violation of the Biblical principle" (Exodus 23:7) (Friedman, 2001, p. 6).

Vendors must be honest in selling. Hiding faults from the buyer is not permitted and such a sale is null and void. The Talmud ... prohibits such deceptions as: mixing your own produce with that of other farmers when the agreement was to provide produce from your field; painting animals or utensils in order to fool prospective buyers into thinking they are younger or new; deceiving potential customers by placing the better quality merchandise on top of the bin (and the lower quality merchandise on the bottom...; selling wine that has become adulterated with water in your store without informing the customers. The laws 
dealing with transactions under mistaken assumptions are relevant even in marriage, i.e., the discovery of a bodily defect in a spouse can nullify the marriage... (Friedman, 2001, p. 7)

\subsection{Corporate Social Responsibility}

The Torah contains many laws dealing with social responsibility. Many of these deal with business practice; “....there are certain standards of exemplary conduct which ....which a conscientious business person should consider binding... [C]onduct of business is not exempt from the general commandment to sanctify God's name by dignified conduct in all our social interactions" ("Value Conflicts," 1996, para. 2).

High ethical practices are prized. Ethical dilemmas must be resolved by applying the Torah and Jewish thought. Balance in corporate social responsibility is desired. Business professionals should not be stingy and fail to support those in need, and should also not be excessive in giving away resources. Non-owner managers of firms may not give away resources that belong to the owners.

Managers of publicly held firms who use company funds for socially responsible ends must do so with full disclosure to all stakeholders. Best practice is to make social responsibility a publicly known policy of the firm. If the manager is acting as an agent for a principal, and the principal has not established guidelines for practice, then the agent would use the typical or normal level of resources for social responsibility action. A Jewish manager would look to the tithe as a starting point for socially responsible action.

A standard goal of a Jewish company is to "do well by doing good." Doing good involves making profits for the firm and taking care of the owners and workers of the firm. The successful firm will make excess profits, some of which can be used to take care of the needy in the community.

The commentator Cliff Lin gives us some perspective on Judaism and Corporate Social Responsibility (Lin, 2013, para. 29), as follows:

Upon investigating the Jewish perspective on Corporate Social Responsibility (CSR), one realizes the necessity to examine two main Jewish ideologies: benevolence and free will (Sherwin, 2006). Benevolence is the highest virtue in Judaism, and it includes a number of desirable qualities, such as caring, forgiving, and giving to the poor. With such emphasis placed on benevolence, it stands to reason that Jewish people would promote the goodwill inherent in CSR. Since we all have free will, we have the choice to be either benevolent or malevolent, qualities that bring about either reward or punishment (Tabory, 1982).

Judaism's high regard for benevolence becomes evident when one considers the fact that, in this religion, virtuous deeds are linked to reward while wicked deeds are associated with punishment... According to Judaism, humans are finite replicas of God and thus carry within them the divine spark of omniscience, omnipotence, and omnibenevolence (Peppard, n.d.). Since human beings cannot possibly portray all three characteristics to their fullest extent, munificence ought to be the life-long goal of every person.

However, Judaism does not necessarily insist on the practice of CSR. Acting benevolently is merely a noble suggestion, since avoiding acts of malevolence is enough to counteract to threat of Hell. Whether one goes above and beyond the moral call of duty depends entirely upon free will. Judaism states that, while every human has the choice to commit either good or bad deeds, each of our actions brings about a certain consequence (Tabory, 1983). While acting maliciously elicits punishment of the soul, acting neutrally, without either positive or negative intent, brings on no such retribution. Still, one would be well advised to act with the welfare of others in mind, since compassion inevitably leads to reward.

It is helpful here to consider a particular Jewish-based firm and its corporate social responsibility practices. The firm is OGR Stock Denton, a law firm based in London, England. The following statements are taken from OGR's Statement of Corporate Social Responsibility:

At OGR Stock Denton we have a comprehensive Corporate Social Responsibility (CSR) strategy to ensure we do our best for the local and wider community, employees and the environment. Our programme encourages members of staff to engage with other businesses, charities and community groups. The strategy has helped foster closer working relationships between our members of staff and ensures that the firm continues to be a positive, active participant in local events. We invest a considerable amount of time supporting various charitable causes, organising fundraising activities and offering third sector organisations advice on various legal matters. OGR Stock Denton LLP recently offered work placements to two people with learning difficulties as part of an initiative run by the charity Langdon UK. Several of our solicitors provide pro bono advice to various different organisations. The firm is highly aware of the 
environmental impact of our activities and those of our suppliers. To this end we have introduced a number of initiatives to improve waste management and recycling and reduce our energy consumption/carbon footprint. The well-being, career and personal development of each and every one of our employees is very important to us and we believe it is important that the team enjoys a healthy work-life balance. (OGR, 2017, para 1)

\subsection{Human Resource Management}

The business environment continues to evolve and adapt in response to globalization. With the emergence of the global business environment has come a marked shift in human resource management practices. The focus of human resource management has evolved from a primarily administrative function to a strategic function, playing an integral role in the overall success and viability of an organization.

"Religious foundations of human resource strategies are important but are rarely highlighted in the literature" (Ali, Gibbs, \& Camp, 2000, p. 118). There are several human resource management practices that stem from religious beliefs of Judaism, as well as other world religions. There are several human resource management principles that can be traced back to the Ten Commandments. The commandment to honor the Sabbath acknowledges that hard work is tiring and rest is needed to rejuvenate and maintain one's health and strength. Most organizations acknowledge that working too much is not healthy and therefore offer employees regularly scheduled days off each week. The importance of time away from work is also acknowledged by many Western countries as demonstrated through labor laws that require organizations to pay workers additional compensation for hours worked in addition to the regular work week. In the Jewish tradition, all workers are granted a day of rest each week (Jewish Labor Committee, 1993).

Many workplace violence policies stem from the commandment "You shall not murder." Most organizations today have policies in place that forbid violent, aggressive, and abusive behavior among employees. Recently a company in Owings Mills, Maryland was issued violations and fines by the Occupational Health and Safety Administration (OSHA) after an employee was murdered (Maurer, 2013). In the Jewish tradition, workers should be protected from harm by employers, as "'the Torah obligates [the employer] to make every effort to protect his workers from injury" (Jewish Labor Committee, 1993, p. 9).

Sexual harassment and hostile work environment policies relate to the commandment that "You shall not commit adultery." Just as inappropriate sexual relationships wreak havoc in family life, they are also very disruptive to the organizational environment. There are numerous cases where supervisors and employees have had inappropriate sexual relations which resulted in significant legal issues, financial issues, and company disgrace. Recently a jury awarded a sexual harassment claimant nearly $\$ 8$ million in damages that resulted from manager negligence at a Chipotle restaurant (Long, 2016). In another case, the Equal Employment Opportunity Commission (EEOC) held that Costco was liable for failure to intervene against a customer who harassed an employee, thereby creating a hostile work environment. The jury awarded the victim $\$ 250,000$ in compensatory damages (EEOC, 2016). "The Torah repeats several times the phrase 'lo tikrevu', meaning, 'you shall not draw near.' This implies a far wider prohibition than the illicit physical relationship itself by the Talmud. Any semblance of inappropriate sexual behaviour crosses clearly defined red lines" (Birnbaum, 2016, para. 8).

The commandments "You shall not steal" and "You shall not bear false witness against your neighbor" have encouraged a host of workplace policies related to honesty, integrity, and ethics. Often codified in a Code of Conduct document, organizations outline expectations related to moral and ethical behavior for employees. Policies often include the requirement to be honest and truthful in all business dealings, as well as expectations related to respect of company property and notice that stealing company property is strictly prohibited. Deploying company resources for personal use is also forbidden. "An employee may not use the property of his employer or the employer's firm for his own personal purposes. He must therefore refrain from using the company's telephone, copier, other machinery, car, etc." (Wenger, n.d., para. 7).

\subsection{Conducting Business in Israel}

"With virtually no natural resources [Israel] has created the highest standard of living in the Middle East, and is home to the highest number of NASDAQ-listed companies anywhere outside of the United States ..." (Solomon \& Schell, 2009, p. 18).

The two official languages of Israel are Hebrew and Arabic. However, much of business is conducted in English. Approximately $80 \%$ of Israeli citizens are Jewish; the remainders are largely Arabs, and most of the Arabs are Sunni 
Muslims. The following paragraphs deal with conducting business with Israeli Jews. Conducting business with Israeli Arabs will be considerably different (Katz, 2011).

"The Israeli legal system is based in common law, which also incorporates facets of civil law. Israel does not have a formal Constitution. Laws enacted by the Knesset, particularly the Basic Laws of Israel, provide the framework of Israeli law, which is enriched by political and judicial precedent" ("Legal System," 2017, para. 3).

Business professionals from the United States will typically find their Israeli business partners similar in orientation and drive, as Israel is increasingly individualistic in culture, and independent decision-making is prized.

Israelis want to avoid uncertainty, as illustrated by a Hofstede index number of 81 on Uncertainty Avoidance. They like structure and want things planned out in advance. They do not like to waste time.

"Subjective feelings tend to be the basis for the truth. However, faith in the ideologies of Judaism, including the fact that the state must succeed, problems have to be solved, and security has to be maintained, may modify the truth as one sees it. Objective facts are used to supplement feelings and faith" (Morrison \& Conaway, 2006, p. 260).

Men and women are treated almost equally. There can be good camaraderie between bosses and employees. Business partners can be called by their first names. Shaking hands is good. Maintain good eye contact. Exchanging business cards is increasingly done. Get straight to the point without being obnoxious. Expect your business partners to be quite direct in communication. Israelis are typically polychromic.

Make sure you order only kosher food at mealtime. Avoid jokes and too much levity since your Israeli business partner may think you are not serious about your work. There won't be much small talk at the beginning of business sessions. U.S. type gestures are normally acceptable.

Wear a suit until you establish a relationship with your Israeli business partner, then wear clothes similar to those of that partner. Often the business attire of Israel is quite casual, including the wearing of jeans.

Be careful not to get into conversations about political matters, particularly discussions about the Palestinian-Israeli conflict. Whatever the topic, be prepared for a vigorous and maybe even boisterous conversation, with many interruptions of your presentation; this may be unnerving to a U.S. businessperson.

Israeli business professionals are typically good negotiators. They would expect several rounds of negotiations and would assume that you, the businessperson from the United States, would also prefer extended negotiations. Pressure techniques may be used, such as making final offers, but usually the final offer is not the real final offer. Negotiations may be emotional, and attempts made to make you feel guilty in your bargaining stance. This does not conflict with Jewish beliefs because they likely view your presence at the table means you are not suffering financially.

Be sure to capture all agreements in writing, for the written word is deemed more important that the oral commitment. Expect many details to be placed in contracts.

Don't give expensive gifts, for the gifts may be seen as bribery. Stay away from bribery at all costs.

Remember that Saturday is the Sabbath for Jews, so don't expect to do business on Saturdays.

\subsection{Conducting Business in Europe}

Jewish business practices in Europe are similar to business practices in the United States. However, Jewish business professionals may face much more discrimination than they would face in the United States.

European attitudes toward Jews was described by a poll done by the Anti-Defamation League in 2015. A poll was taken in 19 countries, and a discrimination index was developed on a scale of 1-100, with the high number representing the most discrimination. Respondents were asked to respond to such statements as: Jews have too much power in the business world; and Jews have too much power in international financial markets ("ADL Global," 2015).

Country indices from this poll were: Greece: 67; Italy: 29; Spain: 29; Belgium: 21; France: 17; Germany: 16; and United Kingdom: 12. Turkey, on two continents, had an index number of 71 (“Index,” 2015).

There has been a rise in recent years of xenophobia and anti-Semitism in Europe, which has many Jewish business professionals reconsidering their locale. Israeli Prime Minister Benjamin Netanyahu has called for European Jews to immigrate to Israel because of the increased anti-Semitism in Europe. Journalists in Britain and France have engaged in a number of experiments to gage the extent of anti-Semitism, and the results have revealed that negative attitudes 
towards Jews are common. However, there is fear that if Jews leave Europe to any great extent, the European economy will suffer ("If Jews Leave," 2015).

\section{Conclusion}

Today's global business environment continues to become more diverse. Business professionals therefore must be proactive in gaining the requisite knowledge and skills to successfully conduct business on an international scale. Business professionals engaged in global business need to understand the customs, beliefs and practices of Judaism and the resulting Jewish business practices that they inform. Considering the dynamic economy of Israel as well as the extent to which Jewish business professionals are engaged in the global business environment, it makes it quite likely that a typical U.S. business professional will interact at some time with Jewish business professionals, and therefore should be well-versed in Jewish business practices.

In this paper the authors have provided a brief explanation of Judaism, including an overview of its history and major beliefs. Subsequently, a review of several Jewish business practices that originate from the traditions and beliefs of Judaism were described. Jewish business practices related to attitudes toward wealth in business, business ethics, corporate social responsibility, and human resource management all are deeply rooted in Judaism. Furthermore, there are specific approaches to conducting business with Israelis as well as conducting business in Europe that can greatly assist business professionals in successfully interacting with Jewish business professionals. These descriptions give information that every businessperson working in the global business environment should know. It is hoped this paper will influence the reader to study Jewish history and the writings that are sacred to Jews. Further, it is hoped readers will be appreciative of Jews and will thereby be better able to strengthen the relationships between Jews and others.

\section{References}

Ali, A.J., Gibbs, M., \& Camp, R.C. (2000). Human resource strategy: The Ten Commandments perspective. International Journal of Sociology and Social Policy, 20(5/6), 114-132.

ADL Global. (2015). An index of anti-semitism. Retrieved from http://global100.adl.org/\#map/country

Birnbaum, Y. (2016). Torah's take on sexual abuse. The Jewish Chronicle. Retrieved October 26, 2016, from https://www.thejc.com/comment/comment/torah-s-take-on-sexual-abuse-1.54243

Circumcision. (n.d.). B'rit Milah: The circumcision ritual. Retrieved from http://www.reformjudaism.org/brit-milah-circumcision-ritual

Dobbs, R., Remes, J., Smit, S., Manyika, J., Woetzel, J., \& Agyenim-Boateng, Y. (2013, October). Urban world: The shifting global business landscape. McKinsey Global Institute. Retrieved from http://www.mckinsey.com/global-themes/urbanization/urban-world-the-shifting-global-business-landscape

Dunn, S.L., \& Galloway, R.R. (2011, November). Islam, Islamic finance, and Christianity. Journal of Biblical Integration in Business, 14(1), 43-67.

Equal Employment Opportunity Commission. (2016). EEOC wins jury verdict in sexual harassment case against Costco. Retrieved July 28, 2017, from https://www.eeoc.gov/eeoc/newsroom/release/12-22-16.cfm

Ethical Treatment. (n.d.). Ethical treatment of animals in Judaism. My Jewish Learning. Retrieved July 31, 2017, from http://www.myjewishlearning.com/article/ethical-treatment-of-animals-in-judaism

Friedman, H.H. (1985). Ethical behavior in business: A hierarchical approach from the Talmud. Journal of Business Ethics, 4, 117-129. https://doi.org/10.1007/BF00383564

Friedman, H.H. (2001). The impact of Jewish values on marketing and business practices. Journal of Macromarketing, 21, 74-80. https://doi.org/10.1177/0276146701211007

Geffen, W. (n.d.). What to expect at a Reform Shabbat service. Retrieved July 31, 2017, from http://reformjudaism.org/what-expect-reform-shabbat-service

Hofstede, G, Hofstede, G.J., \& Minkov, M. (2010). Cultures and organizations: Software of the mind. New York: McGraw Hill.

Hofstede, G. (n.d.). What about Israel? Retrieved from https://geert-hofstede.com/israel.html

Holmes, G. (1988). The Oxford illustrated history of medieval Europe. New York: Oxford.

If Jews leave, Europe will face 'economic disaster', Jewish leader warns. (2015). Retrieved March 10, 2015, from https://www.rt.com/news/239285-europe-economic-disaster-jews/ 
Index. (2015). An index of anti-semitism. Retrieved from http://global100.adl.org/\#map/2015update

Jackson, G. (1972). The making of medieval Spain. Norwich, Great Britain: Harcourt Brace Jovanovich.

Jewish Labor Committee. (1993). Labor rights in the Jewish tradition. Retrieved July 28, 2017, from http://www.jewishlaborcommittee.org/LaborRightsInTheJewishTradition.pdf

Katz, L. (2011). Negotiating international business: The negotiator's reference guide to 50 countries around the world. Amazon Digital Services.

Kohler, K. (2015). Jewish theology: Systematically and historically considered. New York: Andesite Press.

Kosher. (n.d.). What does Kosher mean? Retrieved July 31, 2017, from http://www.koshercertification.org.uk/whatdoe.html

Kosher Overview. (n.d.). What is Kosher? General overview. Retrieved July 31, 2017, from http://www.sealk.org/what-is-kosher/

Koys, D.J. (2001, May). Integrating religious principles and human resource management activities. Teaching Business Ethics, 5(2), 121-139. https://doi.org/10.1023/A:1011490913223

Legal System. (n.d.). The Israeli courts and legal system: A brief synopsis. Retrieved July 31, 2017, from https://unitedwithisrael.org/the-israeli-courts-and-legal-system-a-brief-synopsis/

Lin, C. (2013). Religion \& corporate social responsibility. Retrieved from http://www.cliffordlin.com/religion-and-corporate-social-responsibility

Long, H. (2016). Chipotle to pay 16-year-old nearly $\$ 8$ million for 'outrageous' sexual assault. CNN Money. $\begin{array}{llll}\text { Retrieved } & \text { September } & 29, & \text { 2016, }\end{array}$ http://money.cnn.com/2016/09/29/news/chipotle-teen-worker-wins-sexual-assault-case/index.html

Maurer, R. (2013). OSHA cites company in murder of employee. Society for Human Resource Management. Retrieved June 26, 2013, from https://www.shrm.org/ResourcesAndTools/hr-topics/risk-management/Pages/OSHA-Cites-Company-Murder-E mployee.aspx

Messiah. (n.d.). Mashiach: The Messiah. Judaism 101. Retrieved July 31, 2017, from http://www.jewfaq.org/mashiach.htm

Messianic. (n.d.). What is Messianic Judaism? Retrieved July 31, 2017, from https://www.gotquestions.org/Messianic-Judaism.html

Mitzvot. (2011). A list of the 613 Mitzvot. Retrieved from http://www.jewfaq.org/613.htm

Morrison, T., \& Conaway, W.A. (2006). Kiss, bow, or shake hands (2nd ed.). Avon, MA: Adams Media.

OGR. (2017). Statement on Corporate Social Responsibility. Retrieved from https://www.ogrstockdenton.com/about-us/corporate-social-responsibility/

Orthodox. (2017). Orthodox Jewish population rising in the U.S. Retrieved from https://www.hidabroot.com/article/192393/Orthodox-Jewish-Population-Rising-in-US

Peppard, M. (n.d.). Reclaiming the postmodern Jew. The Free Library. Retrieved July 31, 2017, from https://www.thefreelibrary.com/Reclaiming+the+postmodern+Jew.-a0106730944

Sacks, J. (2010). Genesis: The book of beginnings. Amazon Digital Services.

Sherwin, B. (2006). The assimilation of Judaism: Heschel and the 'category mistake'. Judaism, 55(3-4), 40-50. Retrieved from https://www.questia.com/magazine/1G1-171034148/the-assimilation-of-judaism-heschel-and-the-category

Solomon, C.M., \& Schell, M.S. (2009). Managing across cultures. New York: McGraw Hill.

Southern, R.W. (1953). The making of the Middle Ages. New Haven, CT: Yale.

Synagogue. (n.d.). Synagogue services. Retrieved July 31, 2017, from http://www.ijs.org.au/Synagogue-services/default.aspx

Tabory, E. (1983). Reform and Conservative Judaism in Israel: A social and religious profile. American Jewish Year Book. Retrieved from https://www.jstor.org/stable/23604806?seq=1\#page_scan_tab_contents 
Tole, J.T. (2012). Israel's high power/low power \& high/low uncertainty avoidance. Retrieved from https://jarretttole.wordpress.com/2012/10/09/israels-high-powerlow-power-highlow-uncertainity-avoidance/

Torah. (n.d.). The Torah: Five books of story, law, and poetry divided into 54 weekly portions. My Jewish Learning. Retrieved June 27, 2017, from www.myjewishlearning.com/article/the-torah/

Value Conflicts. (1996.) Value conflicts in Jewish business ethics: Social versus fiduciary responsibility. Retrieved from https://www.jlaw.com/Articles/fiduciary.html

Vital Statistics. (2016). Vital statistics: Jewish population of the world. Retrieved from http://www.jewishvirtuallibrary.org/jewish-population-of-the-world

Wenger, E. (n.d.). The laws of stealing. Chabad.org. Retrieved July 28, 2017, from http://www.chabad.org/library/article_cdo/aid/383785/jewish/The-Laws-of-Stealing.htm

Whitmarsh, T. (1981). Jews, Greeks and Romans. History Today, (72). Retrieved from http://www.historytoday.com/tim-whitmarsh/jews-greeks-and-romans

Zi-Yi, G., \& Yangxiaoteng, L. (2017). Credit constrain export in countries with different degrees of contract enforcement. Business and Economic Research, 7(1), 227-241. https://doi.org/10.5296/ber.v7i1.10923 